\title{
Front Matter: Volume 9459
}

, "Front Matter: Volume 9459," Proc. SPIE 9459, Ocean Sensing and Monitoring VII, 945901 (4 June 2015); doi: 10.1117/12.2201088

SPIE. Event: SPIE Defense + Security, 2015, Baltimore, MD, United States 


\title{
PROCEEDINGS OF SPIE
}

\section{Ocean Sensing and Monitoring VII}

\author{
Weilin W. Hou \\ Robert A. Arnone \\ Editors
}

\author{
21-22 April 2015 \\ Baltimore, Maryland, United States \\ Sponsored and Published by \\ SPIE
}

Volume 9459 
The papers included in this volume were part of the technical conference cited on the cover and title page. Papers were selected and subject to review by the editors and conference program committee. Some conference presentations may not be available for publication. The papers published in these proceedings reflect the work and thoughts of the authors and are published here in as submitted. The publisher is not responsible for the validity of the information or for any outc omes resulting from reliance thereon.

Please use the following format to cite material from this book:

Author(s), "Title of Paper," in Ocean Sensing and Monitoring VII, edited by Weilin W. Hou, Robert A. Amone, Proceed ings of SPIE Vol. 9459 (SPIE, Belling ham, WA, 2015) Article CID Number.

ISSN: 0277-786X

ISBN: 9781628415759

Published by

SPIE

P.O. Box 10, Bellingham, Washington 98227-0010 USA

Telephone +1 3606763290 (Pacific Time)· Fax +1 3606471445

SPIE.org

Copyright @ 2015 , Soc iety of Photo-O ptic al Instrumentation Engineers.

Copying of material in this book for intemal or personal use, or for the intemal or personal use of specific clients, beyond the fair use provisions granted by the U.S. Copyright Law is authorized by SPIE subject to payment of copying fees. The Transactional Reporting Service base fee for this volume is $\$ 18.00$ per article (or portion thereof), which should be paid directly to the Copyright Clearance Center (CCC), 222 Rosewood Drive, Danvers, MA 01923. Payment may also be made electronically through CCC Online at copyright.com. Other copying for republication, resale, advertising or promotion, or any form of systematic or multiple reproduction of a ny material in this book is prohibited except with permission in writing from the publisher. The CCC fee code is 0277-786X/15/\$18.00.

Printed in the United States of America.

Public ation of record for individual papers is online in the SPIE Dig ital Library.

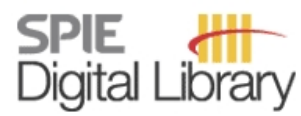

SPIEDigitalLibrary.org

Paper Numbering: Proceedings of SPIE follow an e-First publication model, with papers published first online and then in print. Papers are published as they are submitted and meet publication criteria. A unique citation identifier (CID) number is assigned to each article at the time of the first publication. Utilization of CIDs allows articles to be fully citable as soon as they are published online, and connects the same identifier to all online, print, and electronic versions of the publication. SPIE uses a six-dig it CID artic le numbering system in which:

- The first four digits correspond to the SPIE volume number.

- The last two digits indic ate publication order within the volume using a Base 36 numbering system employing both numerals and letters. These two-number sets start with $00,01,02,03,04$, $05,06,07,08,09,0 A, 0 B \ldots$ OZ, followed by 10-1Z, 20-2Z, etc.

The CID Number appears on each page of the manuscript. The complete citation is used on the first page, and an abbreviated version on subsequent pages. 


\title{
Contents
}

\author{
$\checkmark$ Authors \\ vii Conference Committee
}

\section{CHARACTERIZATION FOR UNDERWATER OPTICAL COMMUNICATIONS}

945909 Underwater optical impulse response measurement using a chaotic lidar sensor [9459-8]

9459 OA Experimental validation of a Monte Carlo model for determining the temporal response of the underwater optical communications channel [9459-9]

UNDERWATER OPTICAL IMAGING AND RANGING I

9459 OB FMCW optical ranging technique in turbid waters [9459-12]

9459 OC Pulse compression techniques to improve modulated pulsed laser line scan systems [9459-13]

9459 OD Distributed compressive sensing vs. dynamic compressive sensing: improving the compressive line sensing imaging system through their integration [9459-14]

9459 OE Semi-empirical inversion technique for retrieval of quantitative attenuation profiles with underwater scanning lidar systems [9459-15]

\section{UNDERWATER OPTICAL IMAGING AND RANGING II}

9459 OF Analysis of polarimetric image by full stokes vector imaging camera for retrieval of target polarization in underwater environment [9459-16]

9459 OG The influence of the choice of the oceanic phase function on imaging under water [9459-17]

$9459 \mathrm{OH}$ A controlled laboratory environment to study EO signal degradation due to underwater turbulence [9459-18]

9459 ol A miniature fiber-optic sensor for high-resolution and high-speed temperature sensing in ocean environment [9459-19]

\section{OCEAN OBSERVATIONS AND MODELS}

9459 0J An expansion of glider observation strategies to systematically transmit and analyze preferred waypoints of underwater gliders [9459-20] 
9459 OK Are the satellite-observed narrow, streaky chlorophyll filaments locally intensified by the submesoscale processes? [9459-21]

9459 OM Bio-optical model of remote sensing signals in a stratified ocean [9459-23]

9459 ON Ocean and polarization observations from active remote sensing: atmospheric and ocean science applications [9459-24]

9459 OP Detecting oil on water using polarimetric imaging [9459-11]

\section{SEA SURFACE TEMPERATURE REMOTE SENSING I}

9459 OR A fast and robust implementation of the adaptive destriping algorithm for SNPP VIIRS and Terra/Aqua MODIS SST [9459-27]

9459 OS Evaluation of VIIRS SST fields through the analysis of overlap regions between consecutive orbits [9459-28]

9459 OT Seasonal trends of ACSPO VIIRS SST product characterized by the differences in orbital overlaps for various water types [9459-29]

9459 OU Suppressing the noise in SST retrieved from satellite infrared measurements by smoothing the differential terms in regression equations [9459-30]

\section{SEA SURFACE TEMPERATURE REMOTE SENSING II}

9459 oY A deterministic inversion technique for sea surface temperature retrieval from MODIS radiances [9459-34]

$94590 Z$ Sensor stability for SST (3S) monitoring system [9459-35]

945910 Identification of sea surface temperature (SST) variability areas through a statistical approach using remote sensing and numerical ocean model data [9459-36] 


\section{Authors}

Numbers in the index correspond to the last two digits of the six-digit citation identifier (CID) article numbering system used in Proceedings of SPIE. The first four digits reflect the volume number. Base 36 numbering is employed for the last two digits and indicates the order of articles within the volume. Numbers start with 00, 01, 02, 03, 04, 05, 06, 07, 08, 09, OA, OB...0Z, followed by 10-12, 20-2Z, etc.

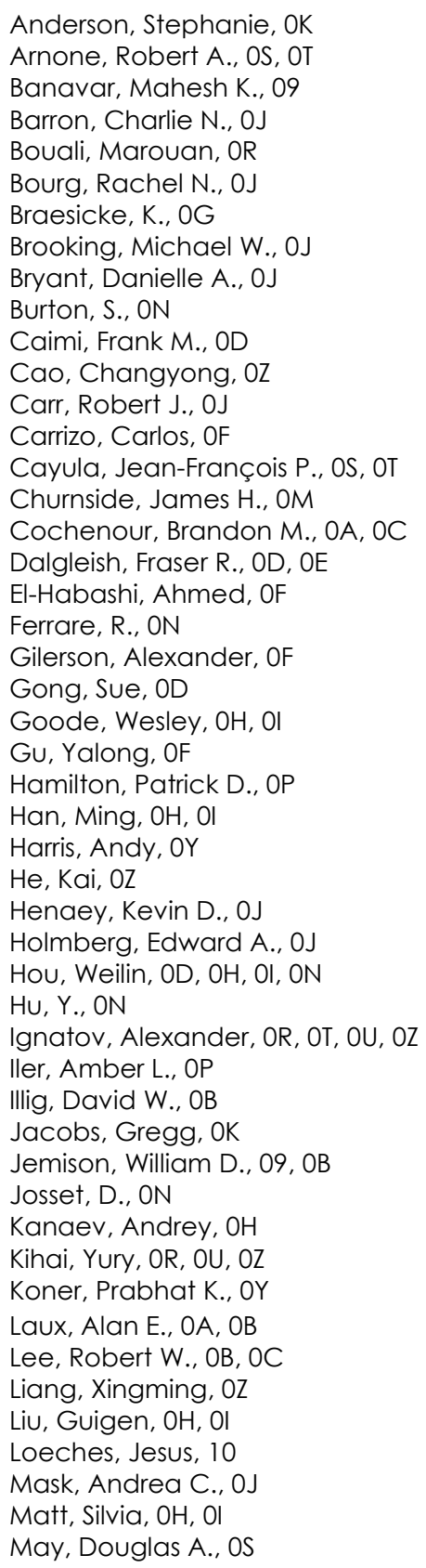

Mensi, Bryan L., OJ

Mikelsons, Karlis, OR

Mullen, Linda J., OB, OC

Nash, Justin K., OC

Ouyang, Bing, OD, OE

Pascal, N., ON

Pelon, J., ON

Pennucci, Giuliana, 10

Penta, Bradley, OK

Petrenko, B., OU

Repasi, E., OG

Restaino, Sergio, $\mathrm{OH}$

Richman, James, OK

Rumbaugh, Luke K., 09

Russo, Aniello, 10

Sakalaukus, Peter, OK

Shulman, Igor, OK

Smedstad, Lucy F., OJ

Stroup, John, $\mathrm{OZ}$

Tanelli, S., ON

Trees, Charles C., OE

Twardowski, Michael S., OE

Vandermeulen, Ryan A., OS, OT

Vicen-Bueno, Raul, 10

Vuorenkoski, Anni K., OD, OE 
Proc. of SPIE Vol. $9459945901-6$

Downloaded From: https://www.spiedigitallibrary.org/conference-proceedings-of-spie on 25 Apr 2023 Terms of Use: https://www.spiedigitallibrary.org/terms-of-use 


\section{Conference Committee}

Symposium Chair

Nils R. Sandell Jr., Strategic Technology Office, DARPA (United States)

Symposium Co-Chair

David A. Logan, BAE Systems (United States)

Conference Chairs

Weilin W. Hou, U.S. Naval Research Laboratory (United States)

Robert A. Arnone, The University of Southern Mississippi (United States)

Conference Program Committee

Samir Ahmed, The City College of New York (United States)

James H. Churnside, National Oceanic and Atmospheric

Administration (United States)

Richard L. Crout, U.S. Naval Research Laboratory (United States)

Alexander Ignatov, NOAA National Environmental Satellite, Data, and Information Service (United States)

Linda J. Mullen, Naval Air Systems Command (United States)

Michael S. Twardowski, WET Laboratories, Inc. (United States)

Brandon Cochenour, Naval Air Warfare Center Aircraft Division

(United States)

Session Chairs

Opening Remarks

Weilin W. Hou, U.S. Naval Research Laboratory (United States)

Robert A. Arnone, The University of Southern Mississippi (United States)

1 Free Space Optical Communications Underwater

Brandon Cochenour, Naval Air Warfare Center Aircraft Division (United States)

2 Characterization for Underwater Optical Communications

Brandon Cochenour, Naval Air Warfare Center Aircraft Division

(United States)

3 Underwater Optical Imaging and Ranging I

Linda J. Mullen, Naval Air Systems Command (United States) 
4 Underwater Optical Imaging and Ranging II

Weilin W. Hou, U.S. Naval Research Laboratory (United States)

Todd E. Bowers, Naval Oceanographic Office (United States)

5 Ocean Observations and Models

Robert A. Arnone, The University of Southern Mississippi (United States)

6 Sea Surface Temperature Remote Sensing I

Alexander Ignatov, NOAA National Environmental Satellite, Data, and Information Service (United States)

7 Sea Surface Temperature Remote Sensing II

Robert A. Arnone, The University of Southern Mississippi (United States)

Jean-François Paul Cayula, Vencore, Inc. (United States) 